\title{
Exploration of Productivity, Chemical Composition, and Antioxidant Potential of Origanum vulgare L. Grown at Different Geographical Locations of Western Himalaya, India
}

\author{
Shweta Goyal $\left(\mathbb{D},{ }^{1,2}\right.$ Geeta Tewari ${ }^{D},{ }^{2}$ H. K Pandey, ${ }^{1}$ and Anjali Kumari ${ }^{1}{ }^{1}$ \\ ${ }^{1}$ Defence Institute of Bio-Energy Research (DRDO), Haldwani 263139, Uttarakhand, India \\ ${ }^{2}$ Department of Chemistry, D. S. B. Campus, Kumaun University, Nainital 263002, Uttarakhand, India \\ Correspondence should be addressed to Shweta Goyal; shwetagoyal17@gmail.com
}

Received 24 December 2020; Revised 12 April 2021; Accepted 18 May 2021; Published 10 June 2021

Academic Editor: Shafaqat Ali

Copyright (C) 2021 Shweta Goyal et al. This is an open access article distributed under the Creative Commons Attribution License, which permits unrestricted use, distribution, and reproduction in any medium, provided the original work is properly cited.

\begin{abstract}
Origanum vulgare L., the most complex and variable species of the genus Origanum, is used to cure various diseases in the traditional medicinal system. In the current investigation, $O$. vulgare was collected from its natural origin and further multiplied for two years at the experimental farm of DIBER field station, Auli, and afterwards, it was grown at three different altitudes, i.e., DIBER field station of Auli (2744 m), Pithoragarh (1524 m), and Haldwani (412 m), under natural field conditions. The essential oil was extracted using the Clevenger apparatus and analyzed by GC/MS and GC/FID. The total phenolic, flavonoid, and tannin content in the methanolic extracts of all the cultivations were estimated by using Folin-Ciocalteu reagent, aluminium chloride reagent, and Folin-Denis methods, respectively. The antioxidant activity of the essential oils and extracts of all the cultivations was also estimated by DPPH, ABTS, and reducing power methods. The highest amount of phenolics, flavonoids, and tannins was obtained in the Pithoragarh cultivation. Thymol was the major component in all the essential oils contributing 38.81\% (Auli), $52.83 \%$ (Pithoragarh), and $31.86 \%$ (Haldwani) of the total oil. The highest antioxidant activity was exhibited by oregano oil of Pithoragarh cultivation, followed by Auli and Haldwani, respectively. The alcoholic extract of Pithoragarh cultivation had the highest antioxidant activity. The study infers that the plant demonstrated good results in terms of fresh weight, oil yield, antioxidant potential, and EO composition when grown at higher altitudes.
\end{abstract}

\section{Introduction}

"Lamiaceae" is widely distributed throughout the Mediterranean, Irano-Turanian, and Euro-Siberian regions [1-3]. It is found in the Himalayas from Kashmir to Sikkim region in India. Locally, it is known as ban tulsi or oregano. It blooms with purple and white flowers and olive green leaves [4]. Although the plant is found in colder areas, it cannot survive in freezing winters and requires hot dry climate for its survival. The essential oil of the plant mainly contains monoterpenoid constituents, but their concentrations vary with geographic location and other factors such as climate, soil, and altitude [5]. The chief components reported in the essential oil of O. vulgare are $\gamma$-muurolene [6], linalool [7], carvacrol [8-10], and thymol $[11,12]$. Besides these, it also contains $p$-cymene, spathulenol, $\gamma$-terpinene, $\beta$-fenchyl alcohol, caryophyllene, germacrene $\mathrm{D}$, and $\delta$-terpineol in minor quantities [13]. Traditionally, the dried herb, leaves, and the essential oil of oregano are used for curing various respiratory problems, rheumatoid arthritis, gastrointestinal disorders, and urinary tract infections [14-17]. The essential oil of $O$. vulgare is a mixture of terpenoid constituents that shows potent antifungal, antihyperglycemic, antiviral, antioxidant, antimutagenic, anti-inflammatory, and antibacterial properties $[5,18,19]$.

Verma et al. proposed that, among the genus Origanum, O. vulgare is the most variable species [20]. The composition of essential oil and its activity are affected by the growing conditions, environmental factors, and harvesting time of the plant [18]. So far, only a few investigations have been reported on its Himalayan population related to its chemical variability $[6,10-12]$. The plant grows naturally at higher 
altitudes and cold climatic conditions. The cost of cultivation of such therapeutically relevant species is high because of less output, i.e., low herbage and essential oil yield. Consequently, its protection is vital for sustainable use. As far as we could possibly know, no work has been accounted on the comparative study of the productivity, variability in the chemical composition, and biological activity of cultivated oregano at different altitudes. Therefore, considering its medicinal importance worldwide, the present investigation was carried out to assess the productivity, chemical composition, and antioxidant potential of $O$. vulgare L. grown at different altitudes under natural climatic conditions.

\section{Materials and Methods}

2.1. Collection and Cultivation. The plant material under investigation was oregano (O. vulgare L.) of the Lamiaceae family which was gathered from Badrinath, Uttarakhand, in the year 2016, and at first, it was kept at the DIBER (Defense Institute of Bio-Energy Research) field station, Auli test field. The plant sample was recognized at the Botanical Survey of India, Dehradun (accession no. 118593). The plant samples were additionally increased and, afterward, were moved in the exploratory plots of the DIBER field station of Auli (OV1), Pithoragarh (OV2), and Haldwani (OV3) with the dispersing of $20^{*} 20 \mathrm{~cm}^{2}$ (Table 1). Different intercultural tasks such as weeding, water system, and farm yard manure (FYM) application were carried out in the test plots. The plants were collected at their separate blooming stages from every one of the three areas followed by washing, and afterward, the new material was utilized for further investigations.

2.2. Isolation of Essential Oil. Five hundred grams of the fresh aerial parts of $O$. vulgare $(\mathrm{OV})$ were accurately weighed from each location. Each slot was hydrodistilled in the Clevenger unit for approximately $4 \mathrm{~h} \mathrm{[21].} \mathrm{The} \mathrm{essential} \mathrm{oils}$ (EOs) obtained were isolated from water, dried over anhydrous sodium sulfate, and stored in glass vials at low temperature $\left(4^{\circ} \mathrm{C}\right)$ before additional investigations.

2.3. Preparation of Extracts. Fifty grams of the powdered plant material was soaked in $250 \mathrm{~mL}$ methanol (ALC) and doubledistilled water (AQ) separately. The solution was placed in an incubator shaker for $24 \mathrm{~h}$. It was centrifuged at $2000 \mathrm{rpm}$ and filtered using Whatman filter paper. Afterward, the solvent was evaporated to dryness on the water bath maintained at $60^{\circ} \mathrm{C}$. The dried extracts OV1 (ALC), OV2 (ALC), and OV3 (ALC) and OV1 (AQ), OV2 (AQ), and OV3 (AQ) were used to carry out the antioxidant analyses.

2.4. Physical Properties of the Essential Oils. Various physical properties such as oil yield (\%), density, refractive index (RI), and color were measured for all the essential oils. The density and RI of the oils were measured with the help of a densitometer (DA-135N) and refractometer (RA-600).
TABLe 1: Geographical data of cultivation sites.

\begin{tabular}{lccc}
\hline Parameters & Auli & Pithoragarh & Haldwani \\
\hline Altitude $(\mathrm{m})$ & 2744 & 1524 & 412 \\
Latitude & $30.52^{\circ} \mathrm{N}$ & $29.58^{\circ} \mathrm{N}$ & $29.22^{\circ} \mathrm{N}$ \\
Longitude & $79.57^{\circ} \mathrm{E}$ & $80.22^{\circ} \mathrm{E}$ & $79.52^{\circ} \mathrm{E}$ \\
\hline
\end{tabular}

\subsection{Chemical Properties of the Essential Oils}

2.5.1. Gas Chromatography/Flame Ionization Detector (GC/ FID) and Gas Chromatography/Mass Spectrometry (GC/MS) Analyses of Essential Oils. GC/MS and GC/FID instruments were utilized for both qualitative and quantitative examinations of the EOs. The quantitative analysis was performed with GC/ FID model 2010 (Shimadzu, Japan) equipped with a CombiPAL AOC-20i/s autosampler (CTC Analytics, Zwingen, Switzerland). One microliter of the neat essential oil was injected by the autosampler. The compounds were separated on an Rxi ${ }^{\circledR}-5$ Sil MS capillary column ( $30 \mathrm{~m}$ length, $0.25 \mathrm{~mm}$ inner diameter, and $0.25 \mu \mathrm{m}$ film thickness). The carrier gas was nitrogen. Injector and detector temperatures were set at $260^{\circ} \mathrm{C}$ and $290^{\circ} \mathrm{C}$, respectively. GC investigation of the essential oil of one area (Pithoragarh) was completed utilizing a different model (Nucon 5765) set as indistinguishable conditions as above. For components' identification, qualitative analysis was performed using model GC/MS QP-2010 (Shimadzu Scientific Instruments, Kyoto, Japan) equipped with a CombiPAL AOC20i/s autosampler (CTC Analytics, Zwingen, Switzerland). The

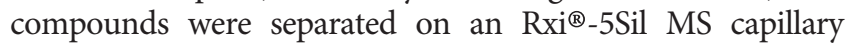
column $(30 \mathrm{~m}$ length, $0.25 \mathrm{~mm}$ inner diameter, and $0.25 \mu \mathrm{m}$ film thickness). The carrier gas was helium at a flow rate of $1.21 \mathrm{~mL} / \mathrm{min}$ with a split ratio of $100: 1$. The injector temperature was $260^{\circ} \mathrm{C}$. The column oven temperature program used was $50^{\circ} \mathrm{C}$ (hold for $2 \mathrm{~min}$ ) to $280.0^{\circ} \mathrm{C}$ at $10^{\circ} \mathrm{C} / \mathrm{min}$ hold for $14 \mathrm{~min}$. The ion source temperature and interface temperature were set at $220^{\circ} \mathrm{C}$ and $270^{\circ} \mathrm{C}$, respectively, and the MS mode was electron impact (EI) at $70 \mathrm{eV}$. The scanning mass range $(\mathrm{m} / z)$ was 40 to 650 . The compounds were separated by $\mathrm{GC}$ and further fragmented by using the mass spectrometer and identified by comparing the mass spectra obtained with NIST14 and WILEY8.LIB from the US National Institute of Standards and Technology (NIST) mass spectra libraries, calculating retention indices (Ri) relative to the homologous alkane series (C9-C33), and the literature data. Quantification of EO components was done by GC/FID peak area $\%$.

2.5.2. Identification of Components. The compounds isolated by GC and fragmented by using the mass spectrometer were identified by comparing the mass spectra and WILEY8.LIB and NIST14 libraries as well as looking at maintenance records (RI) comparative with the homologous alkane standard arrangement (C9-C33) and previous literature data [22]. The peak area percentage obtained by GC/FID measured the quantity of each compound in the essential oil $[23,24]$.

2.6. Antioxidant Activity and Its Constituents. Antioxidant activity of the essential oils, and methanolic and aqueous extracts was evaluated by measuring the free radical 
scavenging activity of various radicals such as DPPH, ABTS, and reducing power [25].

(1) DPPH radical scavenging activity. DPPH (2, 2-diphenyl1-picrylhydrazyl) radical is a long-lived stable free radical which has deep purple color. It abstracts the labile hydrogen atom of the chemical compounds and is utilized to determine the free radical scavenging activity (FRSA) of the essential oils [26]. Different aliquots (10, 20, 30, 40, and $50 \mu \mathrm{L}$ ) of the essential oils, extracts, and standards were prepared, and $2 \mathrm{~mL}(0.135 \mathrm{mM})$ methanolic solution of DPPH was added. The assays were mixed thoroughly and incubated in dark for $30 \mathrm{~min}$. The absorbance was measured at $517 \mathrm{~nm}$ against methanol as the blank. Ascorbic acid was taken as the standard. The antioxidant activity was expressed in terms of $\mathrm{IC}_{50}$ value (the concentration causes $50 \%$ inhibition) from a graph drawn between percent inhibition and concentration. DPPH scavenging activity was calculated by the following equation:

$$
\text { FRSA } \%=\frac{\left\{\text { absorbance }_{(\text {control })}-\text { absorbance }_{(\text {test })}\right\}}{\text { absorbance }_{(\text {control })}} \times 100 .
$$

(2) ABTS radical scavenging activity. the chemical reaction between ABTS (2,2' -azino-bis(3-ethylbenzothiazoline-6-sulfonic acid)) solution and potassium persulfate solution generates the blue-green cation radical ABTS+. This radical is reduced and decolorized by the antioxidant compound which can be measured at $734 \mathrm{~nm}$ absorbance following the method [27]. Different aliquots $(10,20,30,40$, and $50 \mu \mathrm{L})$ of essential oils, extracts, and standard (ascorbic acid) in test tubes were prepared. $1 \mathrm{~mL}$ of ABTS solution (absorbance: $0.702 \pm 0.001$ ) was added to the test tubes, and they were vortexed. The test tubes were incubated in dark for 5-7 min, and absorbance was measured at $734 \mathrm{~nm}$ against methanol as the blank. The antioxidant activity was expressed in terms of $\mathrm{IC}_{50}$ value (the concentration causes 50\% inhibition). ABTS scavenging activity was calculated by using equation (1).

(3) Reducing power. this method is based on the reduction of $\mathrm{Fe}(\mathrm{III})$ to $\mathrm{Fe}(\mathrm{II})$ by the antioxidant compound [28]. In this method, $2.5 \mathrm{~mL}$ of phosphate buffer $(0.2 \mathrm{M}, \mathrm{pH} 6.6)$ was mixed with $1 \mathrm{~mL}$ of each concentration $(10,20,30,40$, and $50 \mu \mathrm{L})$ of the samples (essential oils, extracts, and standard). Then, $2.5 \mathrm{~mL}$ of potassium hexacyanoferrate solution was added to it and incubated at $50^{\circ} \mathrm{C}$ for $20 \mathrm{~min}$. After that, $2.5 \mathrm{~mL}(10 \%)$ of trichloroacetic acid solution was added. The assays were centrifuged at $3000 \mathrm{rpm}$ for $20 \mathrm{~min}$. Afterward, $2.5 \mathrm{~mL}$ of the supernatant was mixed with $2.5 \mathrm{~mL}$ distilled water, and then the mixture was homogenized with $0.5 \mathrm{~mL}(0.1 \%) \mathrm{FeCl}_{3}$ solution. The absorbance was taken at $700 \mathrm{~nm}$ against the buffer solution of all the samples. The oil, extract, and standard concentrations providing 50\% FRAP capacity $\left(\mathrm{EC}_{50}\right)$ were also calculated from the graph of FRAP percentage against concentration.
(4) Total phenolics. the total phenolic content in the plant extracts was estimated by using Folin-Ciocalteu reagent using a reported method [29] with certain modifications. The dried plant extract $(100 \mathrm{mg})$ was accurately weighed, transferred to a volumetric flask, and diluted up to $10 \mathrm{~mL}$ with methanol. The solution was centrifuged (Hanil BioMed Inc., Korea) at 13,000 rpm for $5 \mathrm{~min}$. The supernatant $(100 \mu \mathrm{L})$ was collected and reacted with $200 \mu \mathrm{L}$ of $10 \%$ (v/v) Folin-Ciocalteu reagent. The assay tubes were vortexed for $5 \mathrm{~min}$, and then $800 \mu \mathrm{L}$ of $70 \mathrm{mM} \mathrm{Na}_{2} \mathrm{CO}_{3}$ was added to them. Finally, the assay tubes were incubated at room temperature for $2 \mathrm{~h}$. The absorbance was measured at $765 \mathrm{~nm}$, and the total phenolic content $(\mathrm{mg} / \mathrm{g}$ dry wt. catechol equivalent; $\mathrm{mg} \mathrm{CAE} / \mathrm{g}$ ) was calculated from a standard curve using catechol.

(5) Total flavonoids. the flavonoid content in all the plant extracts was estimated according to the method of Lee and Safinar [30]. The dried plant extract $(100 \mathrm{mg})$ was accurately weighed and transferred into a volumetric flask and made up to the volume $10 \mathrm{~mL}$ with methanol. The solution was centrifuged (Hanil BioMed Inc., Korea) at 13,000 rpm for $5 \mathrm{~min}, 0.5 \mathrm{~mL}$ of the supernatant was taken in an assay tube, and then $1.5 \mathrm{~mL}$ methanol was added to it. Then, $0.1 \mathrm{~mL} 10 \% \mathrm{AlCl}_{3}, 0.1 \mathrm{~mL} 1 \mathrm{M}$ potassium acetate, and $2.8 \mathrm{~mL}$ distilled water were added to the tube. The resulting sample tubes were incubated for $30 \mathrm{~min}$, and finally, the absorbance was taken at $415 \mathrm{~nm}$, and the total flavonoid content (mg/g dry wt. quercetin equivalent; mg QE/ g) was calculated using a standard curve of quercetin.

(6) Total tannins. total tannins in the plant extracts were estimated by the Folin-Denis method [31] in which $0.5 \mathrm{~g}$ of the powdered sample was weighed accurately, and $75 \mathrm{~mL}$ water was added to it. The mixture was boiled for $30 \mathrm{~min}$. Then, it was cooled down and centrifuged at $2000 \mathrm{rpm}$ for $20 \mathrm{~min}$. The supernatant was collected in a volumetric flask of $100 \mathrm{~mL}$, and the volume was made up with distilled water. One milliliter of this mixture was transferred to a $100 \mathrm{~mL}$ volumetric flask containing $75 \mathrm{~mL}$ water. Five milliliters of Folin-Denis reagent and $10 \mathrm{~mL}$ of sodium carbonate solution were added and diluted up to $100 \mathrm{~mL}$ with water. After shaking, the absorbance was taken at $700 \mathrm{~nm}$ after $30 \mathrm{~min}$. The total tannin content $(\mathrm{mg} /$ g dry wt. tannic acid equivalent; mg TAE/g) was measured using a standard curve of tannic acid.

2.7. Statistical Analysis. Mean values and standard deviations (SD) were calculated using MS Excel. Duncan's multiple range tests were applied to compare the mean values with the help of one-way ANOVA by SPSS (16.0) at a significance level of $p<0.05$. Correlation and hierarchical cluster analysis were also performed with the help of SPSS (16.0).

\section{Results and Discussion}

3.1. Productivity. The result of the total fresh plant yield, \% moisture of the fresh and dried plant, and \% ash is given in Table 2. The highest herbage yield was obtained for the Auli 
TABle 2: Percent (\%) moisture and weight of the fresh and dried plant material.

\begin{tabular}{lcccccc}
\hline & Locations & $\begin{array}{c}\text { Plot size } \\
(m \times m)\end{array}$ & $\begin{array}{c}\text { Fresh plant weight } \\
(\mathrm{kg}) \pm \mathrm{SD}\end{array}$ & $\begin{array}{c}\text { \% moisture of the fresh } \\
\text { plant } \pm \text { SD }\end{array}$ & $\begin{array}{c}\text { \% moisture of the dried } \\
\text { plant } \pm \text { SD }\end{array}$ & $\begin{array}{c}\text { \% ash } \pm \text { SD } \\
\text { Origanum }\end{array}$ \\
vulgare L. & Auli & & $3.43^{\mathrm{c}} \pm 0.25$ & $57.30^{\mathrm{a}} \pm 2.48$ & $12.37^{\mathrm{c}} \pm 0.25$ & $9.12^{\mathrm{b}} \pm 1.22$ \\
& Pithoragarh & $2 \times 2$ & $2.70^{\mathrm{b}} \pm 0.26$ & $65.50^{\mathrm{b}} \pm 2.37$ & $3.43^{\mathrm{a}} \pm 0.32$ & $13.03^{\mathrm{a}} \pm 0.48$ \\
& Haldwani & & $0.90^{\mathrm{a}} \pm 0.20$ & $73.61^{\mathrm{c}} \pm 0.58$ & $9.40^{\mathrm{b}} \pm 0.29$ & $11.96^{\mathrm{a}} \pm 0.76$ \\
\hline
\end{tabular}

The mean values within the same column followed by different alphabets $(\mathrm{a}-\mathrm{c})$ in the superscript are significantly different at a significance level of 0.05 ; $\mathrm{SD}=$ standard deviation.

cultivation $(3.43 \mathrm{~kg})$ followed by Pithoragarh $(2.70 \mathrm{~kg})$ and Haldwani cultivations $(0.90 \mathrm{~kg})$, respectively, in the same plot size $(2 \times 2 \mathrm{~m})$. In contrast, the previous results on $T$. serpyllum of the same family showed that the highest herbage yield was obtained at Haldwani cultivation, followed by Pithoragarh and Auli, respectively [32].

\subsection{Essential Oil Yield and Physical Parameters of the Oil.} The findings of Morshedloo et al. showed that the oil yield of O. vulgare L. was highest during the flowering stage $(2.1 \%)$, followed by vegetative (1.66\%), seed set (1.64\%), and early vegetative stages (1.49\%), respectively [5]. Altitude has an indispensable role in the development and growth of medicinal plants. In addition to their amount and quality, altitudinal variation can also significantly modify numerous ecophysiological results [33]. Therefore, the present research was aimed to compare the altitudinal variation in the quality of cultivated O. vulgare oil and extracts at the flowering stage. The results showed great variation in its EO content. The highest yield (Auli, 1.17\%) was obtained at the highest altitude cultivation followed by Pithoragarh $(0.87 \%)$ and Haldwani $(0.08 \%)$ cultivations, respectively (Table 3 ). A positive and significant correlation $\left(r^{2}=.947 ; p<0.01\right)$ was observed between altitude and oil yield (Table 4 ). The variation in the oil yield may be due to the variation in the moisture content, the amount of sunlight received, X-rays, and temperature, as well as light period [33]. The investigation by Mahdavi et al. revealed that the essential oil yield of Tanacetum polycephalum was found to be positively correlated to the altitude of the collection site [34]. In contrast, Habibi et al. and Jamshidi et al. reported that the oil yield of Thymus kotschyanus decreased as the elevation of the collection site increased [35, 36]. According to Goyal et al. [32], the highest essential oil yield for Thymus serpyllum was obtained at the lowest altitude.

The extracted oils were pale yellow in color. The refractive index varied from 1.4817 to 1.4874 , while the density of the oils ranged between 0.920 and $0.931 \mathrm{~g} / \mathrm{mL}$ (Table 3). These parameters differentiate the oil from its adulterant.

\subsection{Chemical Composition}

3.3.1. Essential Oil Composition. The essential oil of the plant mainly contained monoterpenoid constituents, but their concentrations vary with geographic location and other factors such as climate, soil, and altitude [5]. A report by Verma et al. referenced that, among the varieties of Origanum, O. vulgare L. is the most complex species [20]. The chemical composition of the cultivated $O$. vulgare was determined by GC/MS and GC/FID (Figures 1-3). A total of 28,18 , and 24 components were identified in Auli, Pithoragarh, and Haldwani collections representing 97.73\%, $97.68 \%$, and $95.43 \%$ of the total oil, respectively (Table 5). EO of oregano developed at various heights demonstrated an incredible variation in the percentage of major compounds, for example, carvacrol, linalool, caryophyllene, $p$-cymene, camphor, $\gamma$-terpinene, and $\beta$-ocimene. Thymol was the significant compound found in all three areas with the most noteworthy rate in Pithoragarh (52.83\%) trailed by Auli (38.81\%) and Haldwani (31.86\%) developments. Past examinations referenced that the key ingredients in the oil of O. vulgare were thymol and carvacrol $[9,12,37]$, linalool [7], and $\gamma$-muurolene [6]. Other than these, it additionally contained $p$-cymene, caryophyllene, $\gamma$-terpinene, spathulenol, $\beta \beta$-fenchyl liquor, germacrene $\mathrm{D}$, and $\delta$-terpineol in minor quantities [13]. Linalool (4.61-13.00\%) was the subsequent significant compound found in all three areas followed by $p$-cymene $(9.49-10.65 \%)$. The linalool content was observed to be positively correlated with the altitude $\left(r^{2}=.999 ; p<0.01\right)$ of the cultivation site (Table 6). The percentage of $\gamma$-terpinene was the highest in the Haldwani (14.39\%) region, followed by Auli (13.60\%) and Pithoragarh (12.63\%), respectively. Camphor (1.98\%) was just recognized in the Pithoragarh location followed by indole $(0.37 \%)$ in the Haldwani district and terpinen-4-ol (0.94\%) in the Auli area individually (Table 5). The diversity in the chemical composition could be ascribed to ecological elements. Vokou et al. and D'Antuono et al. spoke about the impact of the geographic variety on the oil yield and chemical composition of O. vulgare ssp. hirtum and O. vulgare essential oils from various regions of Greece and Liguria district, Northern Italy of the North Mediterranean region [38, 39]. Previous work by Vokou et al. and Sanli and Karadogan showed that terpenoid biosynthesis is affected by the change in altitude. Oxygenated monoterpenes were observed to be the lowest in $O$. vulgare grown at higher altitudes $[38,40]$. Altitude is, by all accounts, another significant natural factor affecting the composition of essential oil [38]. Also, the natural surroundings of a plant and climatic factors such as warmth and dry season additionally affect the essential oil yield and its composition [41]. Bisht and coworkers mentioned that there was a significant difference in the terpenoid constituents of $O$. vulgare L. collected from different regions of the Northwestern Himalayas. The results of GC and GC/MS showed that the essential oil of oregano from Rilkot and Dhanachuli regions had higher monoterpenoid content, whereas Nainital and Bhowali populations were dominated by sesquiterpenoids. Carvacrol was found in the Dhanachuli 
TABLE 3: Physical parameters and yield of the oils.

\begin{tabular}{lcccc}
\hline Cultivations & Appearance & Oil yield $(\%) \pm S D$ & RI $\left(25^{\circ} \mathrm{C}\right) \pm S D$ & Density $(\mathrm{g} / \mathrm{mL}) \pm \mathrm{SD}$ \\
\hline OV Auli & Pale yellow & $1.17^{\mathrm{c}} \pm 0.15$ & $1.4817^{\mathrm{a}} \pm 0.00$ & $0.9204^{\mathrm{a}} \pm 0.00$ \\
OV Pithoragarh & Pale yellow & $0.87^{\mathrm{b}} \pm 0.02$ & $1.4854^{\mathrm{b}} \pm 0.00$ & $0.9217^{\mathrm{b}} \pm 0.00$ \\
OV. Haldwani & Pale yellow & $0.08^{\mathrm{a}} \pm 0.01$ & $1.4874^{\mathrm{c}} \pm 0.00$ & $0.9316^{\mathrm{c}} \pm 0.00$ \\
\hline
\end{tabular}

The mean values within the same column followed by different alphabets $(a-c)$ in the superscript are significantly different at a significance level of 0.05 ; $\mathrm{SD}=$ standard deviation.

TABLE 4: Correlation between oil yield, altitude, and temperature of the cultivation sites.

\begin{tabular}{lccc}
\hline & Oil yield & Temperature & Altitude \\
\hline Oil yield & 1 & $-0.818^{* *}$ & $0.947^{* *}$ \\
Temperature & & 1 & $-0.953^{* *}$ \\
Altitude & & & 1 \\
\hline
\end{tabular}

${ }^{* *}$ Correlation is significant at the 0.01 level (2-tailed).

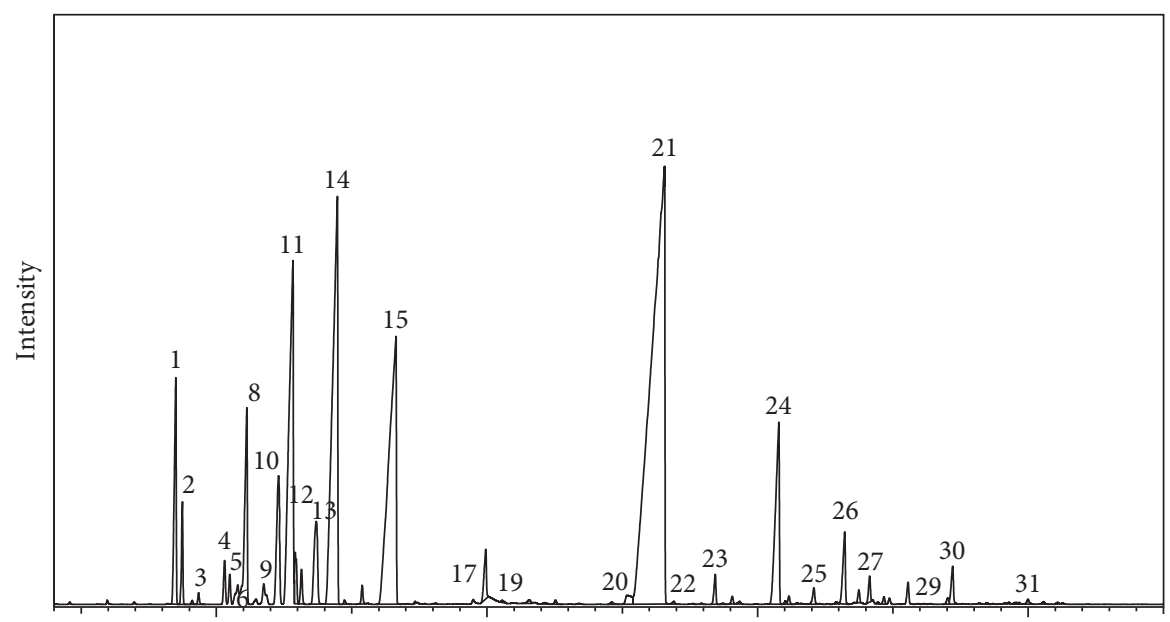

Retention time ( $\mathrm{min})$

Figure 1: Gas chromatogram of the essential oil of O. vulgare grown at Auli (OV1).

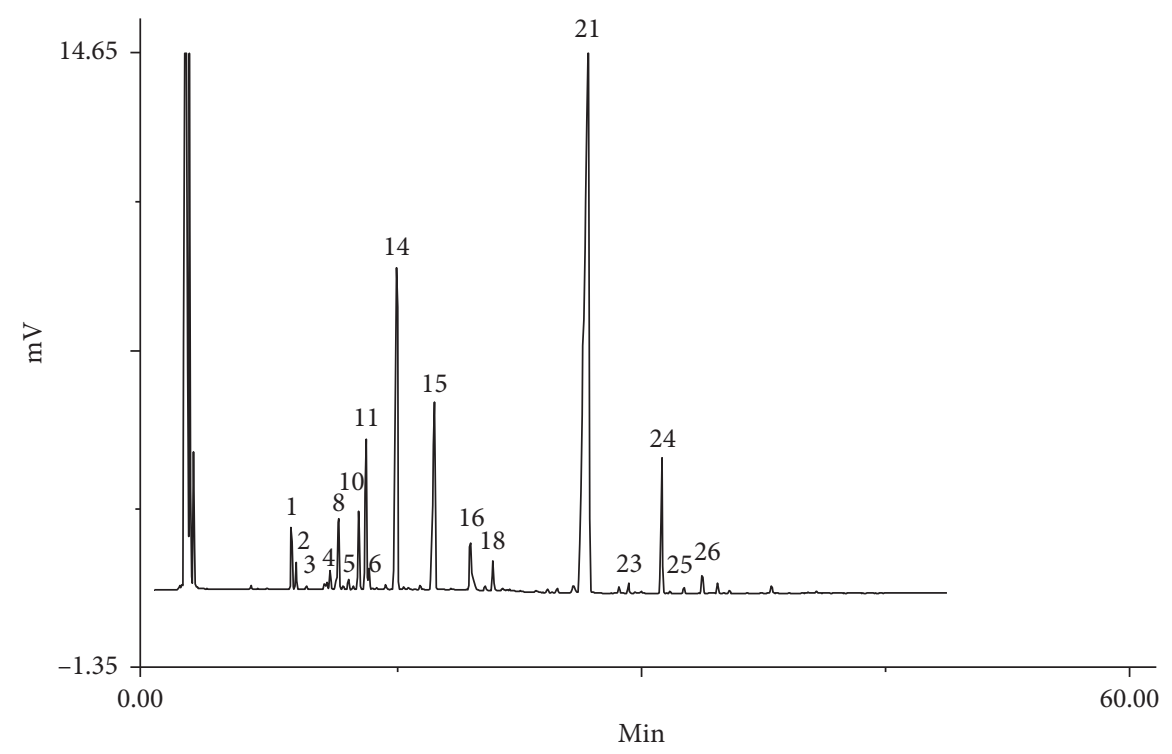

FIgURE 2: Gas chromatogram of the essential oil of O. vulgare grown at Pithoragarh (OV2). 


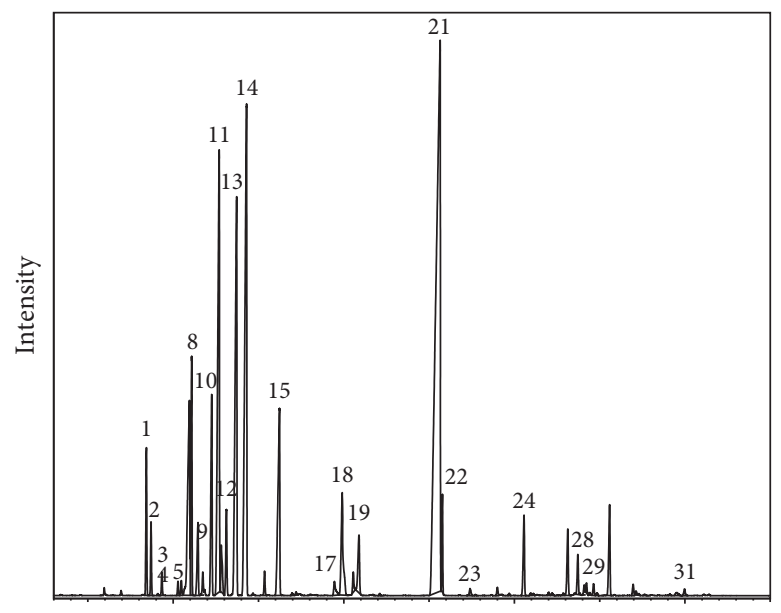

Retention time ( $\mathrm{min})$

FIGURE 3: Gas chromatogram of the essential oil of O. vulgare grown at Haldwani (OV3).

TABLe 5: Chemical constituents identified in the EO of O. vulgare cultivated at different altitudes.

\begin{tabular}{|c|c|c|c|c|c|c|c|}
\hline S. no. & Compound & Class of the compound & $\mathrm{RI}_{\mathrm{cal}}$ & $\mathrm{RI}_{\text {lit }}$ & $\begin{array}{c}\text { Percentage of oil } \pm \text { SD } \\
\text { OV1 }\end{array}$ & $\begin{array}{c}\text { Percentage of oil } \pm \text { SD } \\
\text { OV2 }\end{array}$ & $\begin{array}{c}\text { Percentage of } \\
\text { oil } \pm \text { SD } \\
\text { OV3 }\end{array}$ \\
\hline 1 & $\alpha$-Thujene & $\mathrm{MH}$ & 924 & 924 & $2.89^{\mathrm{b}} \pm 0.02$ & $1.80^{\mathrm{a}} \pm 0.02$ & $1.76^{\mathrm{a}} \pm 0.03$ \\
\hline 2 & $\alpha$-Pinene & $\mathrm{MH}$ & 930 & 932 & $1.35^{\mathrm{b}} \pm 0.03$ & $0.6^{\mathrm{a}} \pm 0.03$ & $2.12^{\mathrm{c}} \pm 0.01$ \\
\hline 3 & Camphene & $\mathrm{MH}$ & 945 & 946 & 0.12 & $0.04 \pm 0.01$ & 0.29 \\
\hline 4 & Sabinene & MH & 970 & 969 & $0.52^{\mathrm{C}} \pm 0.03$ & $0.16^{\mathrm{a}} \pm 0.02$ & $0.19^{\mathrm{b}} \pm 0.01$ \\
\hline 5 & $\beta$-Pinene & $\mathrm{MH}$ & 974 & 974 & $0.32^{c} \pm 0.04$ & $0.16^{\mathrm{a}} \pm 0.01$ & $0.20^{\mathrm{b}} \pm 0.01$ \\
\hline 6 & Octen-3-ol & ALC & 982 & 974 & $0.42^{\mathrm{a}} \pm 0.03$ & $0.46^{\mathrm{b}} \pm 0.04$ & ND \\
\hline 7 & 3-Octanone & KET & 988 & 979 & $\mathrm{ND}$ & ND & $5.44 \pm 0.03$ \\
\hline 8 & $\beta$-Myrcene & MH & 988 & 988 & $3.35^{\mathrm{c}} \pm 0.04$ & $2.50^{\mathrm{a}} \pm 0.03$ & $3.26^{\mathrm{b}} \pm 0.01$ \\
\hline 9 & $\alpha$-Phellandrene & $\mathrm{MH}$ & 1005 & 1002 & $0.42^{\mathrm{b}} \pm 0.05$ & ND & $0.27^{\mathrm{a}} \pm 0.02$ \\
\hline 10 & $\alpha$-Terpinene & $\mathrm{MH}$ & 1018 & 1014 & $2.52^{\mathrm{a}} \pm 0.01$ & $2.75^{\mathrm{a}} \pm 0.04$ & $3.3^{\mathrm{b}} \pm 0.01$ \\
\hline 11 & p-Cymene & $\mathrm{MH}$ & 1028 & 1020 & $9.49^{\mathrm{b}} \pm 0.04$ & $4.81^{\mathrm{a}} \pm 0.05$ & $9.97^{\mathrm{C}} \pm 0.02$ \\
\hline 12 & $D$-Limonene & $\mathrm{MH}$ & 1030 & 1024 & $0.69^{\mathrm{a}} \pm 0.04$ & 0.05 & $0.87^{\mathrm{b}} \pm 0.02$ \\
\hline 13 & $\beta$-Ocimene & $\mathrm{MH}$ & 1050 & 1044 & $1.95^{\mathrm{a}} \pm 0.01$ & ND & $9.47^{\mathrm{b}} \pm 0.02$ \\
\hline 14 & $\gamma$-Terpinene & $\mathrm{MH}$ & 1067 & 1054 & $13.60^{\mathrm{b}} \pm 0.02$ & $14.39^{\mathrm{C}} \pm 0.04$ & $12.63^{\mathrm{a}} \pm 0.02$ \\
\hline 15 & Linalool & $\mathrm{OM}$ & 1105 & 1095 & $13.00^{\mathrm{C}} \pm 0.2$ & $8.51^{b} \pm 0.06$ & $4.61^{\mathrm{a}} \pm 0.02$ \\
\hline 16 & Camphor & $\mathrm{OM}$ & 1146 & 1141 & ND & $1.98 \pm 0.01$ & ND \\
\hline 17 & Borneol & $\mathrm{OM}$ & 1171 & 1165 & 0.08 & ND & $0.36 \pm 0.02$ \\
\hline 18 & Terpinen-4-ol & $\mathrm{OM}$ & 1181 & 1174 & ND & $0.94^{\mathrm{a}} \pm 0.01$ & $2.65^{b} \pm 0.02$ \\
\hline 19 & $\alpha$-Terpineol & OM & 1195 & 1186 & 0.10 & ND & $1.54 \pm 0.01$ \\
\hline 20 & Indole & $\mathrm{AM}$ & 1295 & 1290 & 0.37 & ND & ND \\
\hline 21 & Thymol & $\mathrm{OM}$ & 1310 & 1289 & $38.81^{b} \pm 0.03$ & $52.83^{c} \pm 0.06$ & $31.86^{\mathrm{a}} \pm 0.01$ \\
\hline 22 & Carvacrol & OM & 1312 & 1298 & 0.04 & ND & $1.09^{\mathrm{b}} \pm 0.01$ \\
\hline 23 & Thymol acetate & OM & 1370 & 1370 & $0.38^{\mathrm{c}} \pm 0.01$ & $0.24^{\mathrm{b}} \pm 0.04$ & $0.15^{\mathrm{a}} \pm 0.01$ \\
\hline 24 & Caryophyllene & $\mathrm{SH}$ & 1417 & 1417 & $4.50^{\mathrm{c}} \pm 0.07$ & $3.87^{\mathrm{b}} \pm 0.02$ & $1.41^{\mathrm{a}} \pm 0.01$ \\
\hline 25 & $\alpha$-Humulene & $\mathrm{SH}$ & 1460 & 1452 & $0.23^{\mathrm{a}} \pm 0.02$ & $0.74^{\mathrm{b}} \pm 0.05$ & ND \\
\hline 26 & Germacrene D & SH & 1481 & 1484 & $1.19^{\mathrm{b}} \pm 0.03$ & $0.85^{\mathrm{a}} \pm 0.04$ & ND \\
\hline 27 & Farnesene $<(E, E)-$, alpha- & $\mathrm{SH}$ & 1503 & 1505 & $0.32 \pm 0.01$ & ND & ND \\
\hline 28 & $\beta$-Bisabolene & $\mathrm{SH}$ & 1505 & 1505 & ND & ND & $1.57 \pm 0.04$ \\
\hline 29 & $\gamma$-Cadinene & $\mathrm{SH}$ & 1509 & 1513 & $0.09^{\mathrm{b}} \pm 0.02$ & ND & $0.18^{\mathrm{a}} \pm 0.01$ \\
\hline 30 & Caryophyllene oxide & OS & 1578 & 1582 & $0.58 \pm 0.03$ & ND & $\mathrm{ND}$ \\
\hline 31 & Cadin-4-en-10-ol & OS & 1640 & 1635 & $0.11^{\mathrm{a}} \pm 0.01$ & ND & $0.24^{\mathrm{b}} \pm 0.01$ \\
\hline 32 & $\alpha$-Bisabolene & $\mathrm{SH}$ & 1682 & 1685 & $0.29 \pm 0.04$ & ND & ND \\
\hline \multicolumn{5}{|c|}{ Total compounds identified } & 28 & 18 & 24 \\
\hline \multicolumn{5}{|c|}{ Total \% } & 97.73 & 97.68 & 95.43 \\
\hline
\end{tabular}

$\mathrm{RI}_{\text {cal }}=$ retention index (RI) calculated relative to $n$-alkane homologous series $\left(\mathrm{C}_{9}-\mathrm{C}_{33}\right)$ on the Rtx- 5 column; $\mathrm{RI}_{\text {lit }}=$ library, MS data, and literature (Adams, 2007); mean values within the same row followed by different alphabets $(\mathrm{a}-\mathrm{c})$ at the superscript for specific compounds are significantly different at a significance level of $0.05 ; \mathrm{SD}=$ standard deviation; $\mathrm{MH}$ : monoterpene hydrocarbons (1, 3, 4, 5, 7, and 10-15); ALC: alcohol (6 and 9); KET: ketone (8); AM: alkaloid monoterpene (21); OM: oxygenated monoterpenes (16-20 and 22-24); SH: sesquiterpene hydrocarbons (25-31); OS: oxygenated sesquiterpenes (32-34). 
TABLE 6: Correlation between major components of the essential oil and the climatic condition.

\begin{tabular}{|c|c|c|c|c|c|c|c|c|c|c|}
\hline & p-Cymene & $\beta$-Ocimene & Linalool & Thymol & $\alpha$-Terpinene & $\gamma$-Terpinene & 3-Octanone & Oil yield & Temperature & Altitude \\
\hline p-Cymene & 1 & $0.720^{*}$ & -0.044 & $-0.969^{* *}$ & $-0.934^{* *}$ & $-0.878^{* *}$ & 0.571 & -0.333 & -0.248 & -0.058 \\
\hline$\beta$-Ocimene & & 1 & $-0.724^{*}$ & $-0.868^{* *}$ & -0.426 & $-0.964^{* *}$ & $0.981^{* *}$ & $-0.885^{* *}$ & 0.494 & $-0.734^{*}$ \\
\hline Linalool & & & 1 & 0.287 & -0.315 & 0.515 & $-0.845^{* *}$ & $0.940^{* *}$ & $-0.957^{* *}$ & $0.999^{* *}$ \\
\hline Thymol & & & & 1 & $0.819^{* *}$ & $0.968^{* *}$ & $-0.755^{*}$ & 0.551 & 0.003 & 0.300 \\
\hline$\alpha$-Terpinene & & & & & 1 & 0.650 & -0.241 & -0.020 & 0.577 & -0.302 \\
\hline$\gamma$-Terpinene & & & & & & 1 & $-0.893^{* *}$ & $0.739^{*}$ & -0.245 & 0.527 \\
\hline 3-Octanone & & & & & & & 1 & $-0.954^{* *}$ & 0.654 & $-0.852^{* *}$ \\
\hline Oil yield & & & & & & & & 1 & $-0.818^{* *}$ & $0.947^{* *}$ \\
\hline Temperature & & & & & & & & & 1 & $-0.953^{* *}$ \\
\hline Altitude & & & & & & & & & & 1 \\
\hline
\end{tabular}

${ }^{*}$ Correlation is significant at the 0.05 level (2-tailed). ${ }^{* *}$ Correlation is significant at the 0.01 level (2-tailed).

collection only, while thymol was found in two populations. When the composition was analyzed by enantio-GC, the Bhowali and Dhanachuli populations showed enantiomeric excess for linalool, borneol, $\alpha$-terpineol, terpinen-4-ol, and bornyl acetate [10]. The composition of essential oil and its activity are affected by the growing conditions, environmental factors, and harvesting time of the plant [42]. Verma and coworkers studied the chemical variability of Indian oregano by collecting $17 \mathrm{O}$. vulgare populations from different regions of the Western Himalayas and cultivating at the experimental farm of the Central Institute of Medicinal and Aromatic Plants (CIMAP), Research Centre, Purara, Bageshwar, Uttarakhand [20].

3.3.2. Chemical Composition of Extracts. The total phenolic, total flavonoid, and total tannin content in the methanolic extracts of the samples are expressed in terms of mg CAE/ $\mathrm{g}$, mg QE/g, and mg TA/g, respectively. The highest amount of total phenolics, flavonoids, and tannins was obtained in the Pithoragarh cultivation, followed by Auli cultivation and Haldwani cultivation, respectively (Table 7 and Figure 4). These results indicated that the Pithoragarh sample was rich in phenolic, flavonoid, and tannin contents as compared to the other two samples. The high content of phenolics and flavonoids is also responsible for the high antioxidant activity of the sample. Investigations by Faleiro et al. and Koldaş et al. showed that phenolics and flavonoids are responsible for the high antioxidant activity of oregano [43, 44]. Origanum vulgare L. is a rich source of such antioxidant compounds. Recent work was done on Origanum vulgare L. to evaluate the antioxidant potential and total phenolic and flavonoid contents in the extracts by different extraction procedures, i.e., low-pressure solvent extraction (LPSE), Soxhlet, and ultrasound. The LPSE extracts are found to show the highest inhibition than the other two. $\mathrm{IC}_{50}$ values for all the oregano extracts followed the order, i.e., LPSE $(0.34 \mathrm{mg} / \mathrm{mL})<$ Soxhlet $(3.04 \mathrm{mg} / \mathrm{mL})$ $<$ ultrasound $(6.81 \mathrm{mg} / \mathrm{mL})$. Also, the values for total phenols (10.33-25.15 mg GAE/g) and total flavonoids $(1.69-4.38 \mathrm{mg} / \mathrm{g}$ extract) varied with the extraction procedure [45].

In another investigation by Jain and Bhagia, the total phenolic and total flavonoid content in the oregano extract
TABle 7: Chemical composition of methanolic (OVM) extracts of O. vulgare.

\begin{tabular}{lccc}
\hline Sample & $\begin{array}{c}\text { Total } \\
\text { phenolics } \\
(\mathrm{mg} \mathrm{CE} / \mathrm{g})\end{array}$ & $\begin{array}{c}\text { Total } \\
\text { flavonoids } \\
(\mathrm{mg} \mathrm{QE} / \mathrm{g})\end{array}$ & $\begin{array}{c}\text { Total } \\
\text { tannins } \\
(\mathrm{mg} \mathrm{TA} / \mathrm{g})\end{array}$ \\
\hline OV1 (Auli) & $11.03^{\mathrm{b}} \pm$ & $6.21^{\mathrm{e}} \pm$ & $2.59^{\mathrm{h}} \pm$ \\
OV2 (Pithoragarh) & $12.66^{\mathrm{c}} \pm$ & $7.08^{\mathrm{f}} \pm$ & $2.87^{\mathrm{i}} \pm$ \\
OV3 (Haldwani) & $7.67^{\mathrm{a}} \pm$ & $5.40^{\mathrm{d}} \pm$ & $2.44^{\mathrm{g}} \pm$ \\
\hline
\end{tabular}

Mean values followed by different letters (a-i) are significantly different at the level of $p<0.05$ according to Duncan's multiple test.

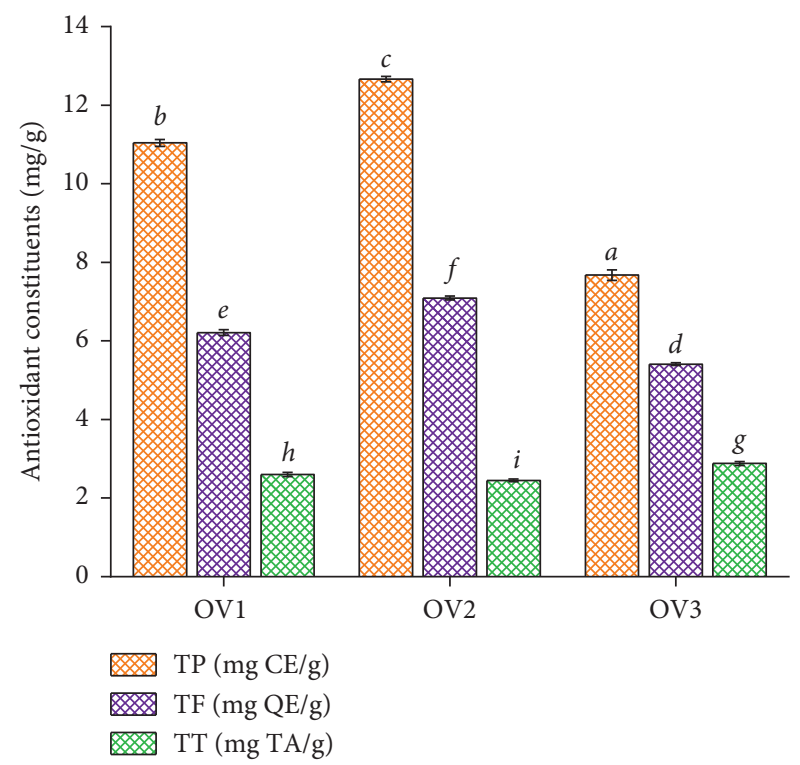

FIGURE 4: Total antioxidant constituents, i.e., phenolics, flavonoids, and tannins, in alcoholic (ALC) extracts of Origanum vulgare from different locations, i.e., Auli (OV1), Pithoragarh (OV2), and Haldwani (OV3).

varied from 23.48 to $98.86 \mathrm{mg} \mathrm{GAE} / \mathrm{g}$ and 14.45 to $19.53 \mathrm{mg}$ quercetin/g, respectively [46].

3.3.3. Antioxidant Activity. The essential oils, as well as their alcoholic and aqueous extracts, were examined for their ability to trap the free radicals and reactive oxygen species (ROS). The results showed that the EOs as well as 
TABLE 8: $\mathrm{IC}_{50}$ and $\mathrm{EC}_{50}$ values for antioxidant assays of essential oils (EOs), aqueous extracts (AQ), and methanolic extracts (ALC) of O. vulgare along with the standard (ascorbic acid).

\begin{tabular}{|c|c|c|c|}
\hline \multirow[b]{2}{*}{ Sample } & \multicolumn{3}{|c|}{ Antioxidant activity $\mathrm{IC}_{50}$ value $(\mathrm{mg} / \mathrm{mL})$} \\
\hline & $\begin{array}{c}\mathrm{DPPH} \\
(\mathrm{mg} / \mathrm{mL})\end{array}$ & $\begin{array}{c}\text { ABTS } \\
(\mathrm{mg} / \mathrm{mL})\end{array}$ & $\begin{array}{l}\text { Reducing power } \\
(\mathrm{mg} / \mathrm{mL})\left(\mathrm{EC}_{50}\right)\end{array}$ \\
\hline OV Auli EO & $1.07^{\mathrm{f}}$ & $0.12^{\mathrm{c}}$ & $0.46^{\mathrm{i}}$ \\
\hline OV Pithoragarh EO & $0.83^{\mathrm{e}}$ & $0.06^{\mathrm{b}}$ & $0.35^{\mathrm{e}}$ \\
\hline OV Haldwani EO & $1.42^{\mathrm{g}}$ & $0.27^{\mathrm{d}}$ & $1.86^{\mathrm{j}}$ \\
\hline OV Auli AQ & $0.74^{\mathrm{d}}$ & $0.56^{\mathrm{i}}$ & $0.38^{\mathrm{f}}$ \\
\hline OV Pithoragarh AQ & $0.49^{\mathrm{c}}$ & $0.44^{\mathrm{g}}$ & $0.33^{\mathrm{d}}$ \\
\hline OV Haldwani AQ & $0.75^{\mathrm{d}}$ & $0.72^{\mathrm{j}}$ & $0.44^{\mathrm{h}}$ \\
\hline OV Auli ALC & $0.50^{\mathrm{d}}$ & $0.43^{\mathrm{f}}$ & $0.32^{\mathrm{c}}$ \\
\hline OV Pithoragarh ALC & $0.39^{\mathrm{b}}$ & $0.32^{\mathrm{e}}$ & $0.29^{\mathrm{b}}$ \\
\hline OV Haldwani ALC & $0.86^{\mathrm{e}}$ & $0.52^{\mathrm{h}}$ & $0.39^{\mathrm{g}}$ \\
\hline Ascorbic Acid & $0.052^{\mathrm{a}}$ & $0.032^{\mathrm{a}}$ & $0.027^{\mathrm{a}}$ \\
\hline
\end{tabular}

Mean values within a column followed by different letters $(a-j)$ are significantly different at the level of $p<0.05$ according to Duncan's multiple test.

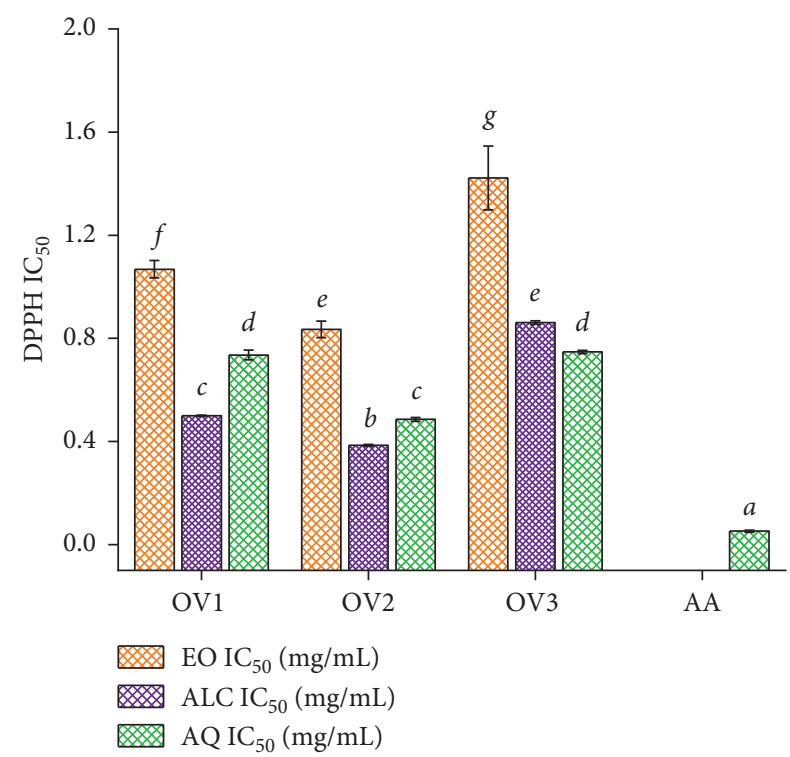

FIGURE 5: IC $_{50}$ plot of DPPH radical scavenging activity of essential oil (EO) and alcoholic (ALC) and aqueous (AQ) extracts of Origanum vulgare from different locations, i.e., Auli (OV1), Pithoragarh (OV2), and Haldwani (OV3).

the extracts possessed remarkable antioxidant activity. Previous studies on the oregano essential oil and its extracts also revealed that they are potent antioxidants and are used worldwide as an essential ingredient in formulations of medicinal and health products [47-50]. In the current investigation, the antioxidant activity was evaluated for various free radicals such as DPPH, ABTS, and ferric ions which showed that the antioxidant activity of the alcoholic extract was the highest followed by aqueous extracts and essential oils. On comparing the results of the $\mathrm{IC}_{50}$ values of EOs and extracts collected from different cultivations, the results followed the order, i.e., OV EO Pithoragarh $>\mathrm{OV}$ EO Auli $>$ OV EO Haldwani, and for the extracts, OV $\mathrm{MeOH}$ Pithoragarh $>\mathrm{OV} \mathrm{MeOH}$ Auli $>\mathrm{OV} \mathrm{MeOH}$

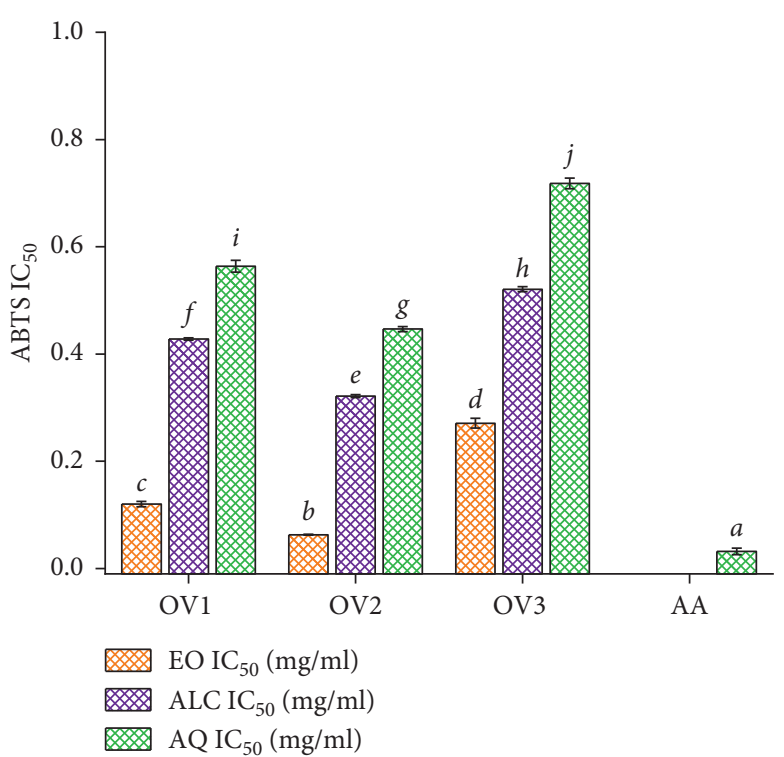

FIGURE 6: $\mathrm{IC}_{50}$ plot of ABTS radical scavenging activity of essential oil (EO) and alcoholic (ALC) and aqueous (AQ) extracts of Origanum vulgare from different locations, i.e., Auli (OV1), Pithoragarh (OV2), and Haldwani (OV3).

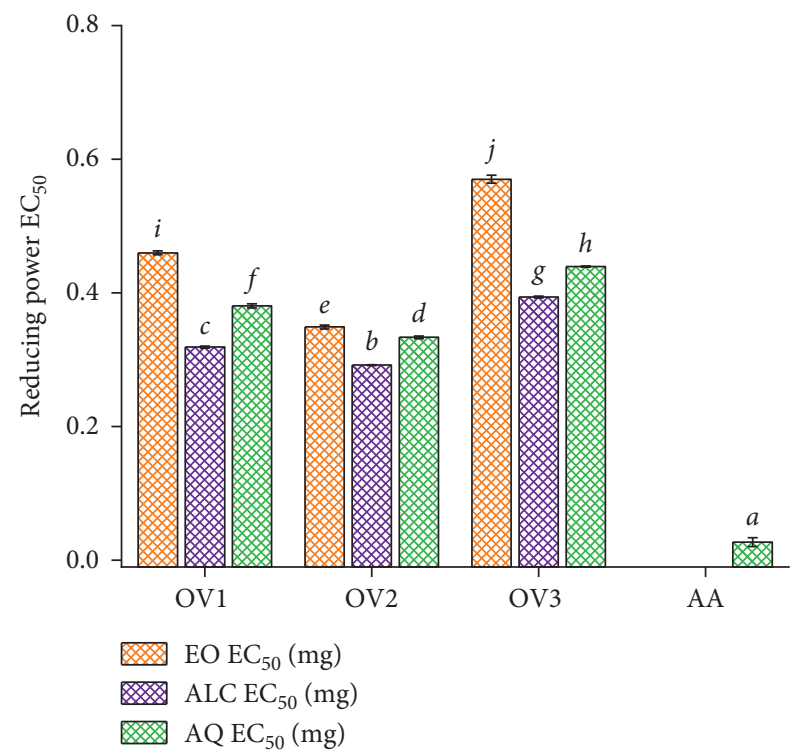

FIGURE 7: $\mathrm{EC}_{50}$ plot of the reducing power ability of essential oil (EO) and alcoholic (ALC) and aqueous (AQ) extracts of Origanum vulgare from different locations, i.e., Auli (OV1), Pithoragarh (OV2), and Haldwani (OV3).

Haldwani and OV Pithoragarh aqueous $>$ OV Auli aqueous $>\mathrm{OV}$ Haldwani aqueous (Table 8 and Figures 5-7). Among the oils, the highest antioxidant activity was shown by Pithoragarh EO. The content of thymol and $\gamma$-terpinene was observed to be negatively correlated with the $\mathrm{IC}_{50}$ values which suggested that, as the thymol and $\gamma$-terpinene percentage increased, the antioxidant potential of the plants also increased (Table 9). Previous results showed that the antioxidant activity of oregano oil was correlated to the 


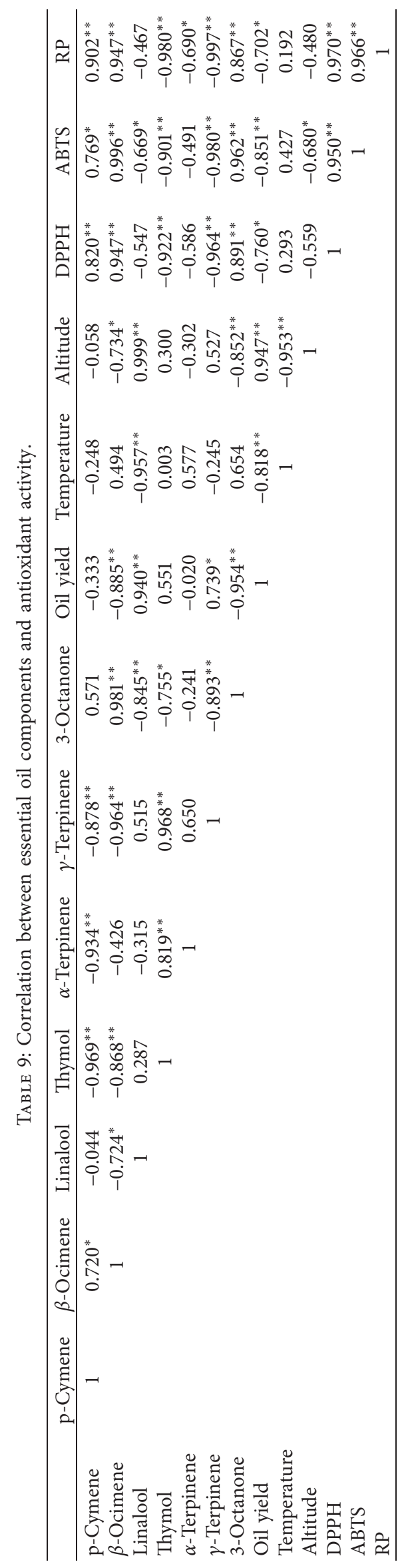


percentage of thymol or carvacrol present in it. The oil harvested at the flowering stage with the highest content of carvacrol showed the highest antioxidant activity. Our observations are in agreement with the previous results of Ozkan et al. [50]. Coccimiglio et al. also mentioned that the methanolic/ethanolic extracts with the high content of isomeric constituents, thymol and carvacrol, showed strong antioxidant, antibacterial, and cytotoxic activities [51]. Recent reports showed that the ethanolic and aqueous leaf extracts of the plant were given to farmed fish in appropriate concentration which showed cytotoxic, immunostimulant, and bactericidal activities. So, it can be used as an additive in the farmed fish diet $[5,52]$. A report from the United States Department of Agriculture showed that oregano oil is very beneficial if it is included in a healthy diet and active lifestyle [53].

In spite of the fact that in vitro assays done were all electron transfer based, the outcomes obtained were significantly different because of their different mechanisms involved in each in vitro assay and kinetics of radical inactivation [54]. Antioxidant activity was calculated by the ability of the sample to trap the free radicals. The free radicals are labile species which were regularly created at an uncontrolled rate in the response medium because of change in reaction conditions. To feature the significant ones, the activity of the antioxidant compound (say for polyphenols) is a component of $\mathrm{pH}$, light, and the presence of favorable oxidants in the response medium which frequently brings about variations in the outcomes obtained [55]. Therefore, in the present study, different antioxidant assays were carried out.

\section{Conclusion}

The study concludes that O. vulgare L. is a rich source of antioxidants. Essential oil and the extracts prepared from these plants have a long history of use in preparing medicines, cosmetics, and food preservatives. Keeping their importance in various fields, there is a need to preserve such plants so that their easy availability can balance the high-cost production. Besides this, another important aspect was to systematically investigate their chemical composition for sustainable use. The results of qualitative and quantitative analyses as well as antioxidant activity revealed that the plant is suitable to grow at high altitudes only where its chemical constituents are preserved.

\section{Data Availability}

The GC-FID and GC-MS data used to support the findings of this study are included within this manuscript.

\section{Conflicts of Interest}

The authors declare that they have no conflicts of interest.

\section{Acknowledgments}

The authors are grateful to the Director, DIBER, Haldwani, and Head, Department of Chemistry, DSB Campus,
Kumaun University, Nainital, for providing necessary laboratory facilities. The authors are also thankful to the Director, DIBER, Haldwani, for the financial support.

\section{References}

[1] N. Aligiannis, E. Kalpoutzakis, S. Mitaku, and I. B. Chinou, "Composition and antimicrobial activity of the essential oils of Two Origanum species," Journal of Agricultural and Food Chemistry, vol. 49, no. 9, pp. 4168-4170, 2001.

[2] M. Skoula and J. B. Harborne, "The taxonomy and chemistry of Origanum," Oregano: The Genera Origanum and Lippia, vol. 67, 2002.

[3] F. Sözmen, B. Uysal, E. O. Köse, Ö. Aktaş, I. Cinbilgel, and B. S. Oksal, "Extraction of the essential oil from endemic Origanum bilgeri P.H.davis with two different methods: comparison of the oil composition and antibacterial activity," Chemistry \& Biodiversity, vol. 9, no. 7, pp. 1356-1363, 2012.

[4] J. H. Ietswaart, "A taxonomic revision of the genus origanum (labiatae)," in A Taxonomic Revision of the Genus Origanum (Labiatae)Leiden University Press, The Hague, Netherlands, 1980.

[5] M. R. Morshedloo, H. Mumivand, L. E. Crake, and F. Maggi, "Chemical composition and antioxidant activity of essential oils in O. vulgare subsp. gracile at different phonological stages and plant parts," Journal of Food Processing and Preservation, vol. 8, 2017.

[6] C. Pande and C. S. Mathela, "Essential oil composition of Origanum vulgare L. ssp. vulgare from the Kumaon Himalayas," Journal of Essential Oil Research, vol. 12, no. 4, pp. 441-442, 2000.

[7] M. M. Carmo, S. Frazão, and F. Venancio, "The chemical composition of Portuguese Origanum vulgare oils," Journal of Essential Oil Research, vol. 33, pp. 69-71, 1989.

[8] D. Mockute, G. Bernotiene, and A. Judzentiene, "The essential oil of Origanum vulgare L. ssp. vulgare growing wild in vilnius district (Lithuania)," Phytochemistry, vol. 57, no. 1, pp. 65-69, 2001.

[9] K. Can Baser, "Biological and pharmacological activities of carvacrol and carvacrol bearing essential oils," Current Pharmaceutical Design, vol. 14, no. 29, pp. 3106-3119, 2008.

[10] D. Bisht, C. S. Chanotiya, M. Rana, and M. Semwal, "Variability in essential oil and bioactive chiral monoterpenoid compositions of Indian oregano (Origanum vulgare L.) populations from northwestern Himalaya and their chemotaxonomy," Industrial Crops and Products, vol. 30, no. 3, pp. 422-426, 2009.

[11] C. Pande, G. Tewari, S. Singh, and C. Singh, "Chemical markers in Origanum vulgare L. from Kumaon Himalayas: a chemosystematic study," Natural Product Research, vol. 26, no. 2, pp. 140-145, 2012.

[12] R. S. Verma, R. C. Padalia, and A. Chauhan, "Volatile constituents of Origanum vulgare L., "thymol" chemotype: variability in North India during plant ontogeny," Natural Product Research, vol. 26, no. 14, pp. 1358-1362, 2012.

[13] B. Teixeira, A. Marques, C. Ramos et al., "Chemical composition and bioactivity of different oregano (Origanum vulgare) extracts and essential oil," Journal of the Science of Food and Agriculture, vol. 93, no. 11, pp. 2707-2714, 2013.

[14] D. Ivanova, T. Gerova, T. Chervenkov, and T. Yankova, "Polyphenols and antioxidant capacity of Bulgarian medicinal 8 oxidative medicine and cellular longevity plants," Journal of Ethnopharmacology, vol. 96, no. 1-2, pp. 145-150, 2005. 
[15] Y. T. Lin, Y. I. Kwon, R. G. Labbe, and K. Shetty, "Inhibition of Helicobacter pylori and associated urease by oregano and cranberry phytochemical synergies," Applied and Environmental Microbiology, vol. 71, no. 12, pp. 8558-8564, 2005.

[16] G. B. Mahady, S. L. Pendland, A. Stoia et al., "In Vitro susceptibility of Helicobactor pylori to botanical extracts used traditionally for the treatment of gastrointestinal disorders," Phytotherapy Research, vol. 19, no. 11, pp. 988-991, 2005.

[17] C. C. Rosenbaum, D. P. O’Mathúna, M. Chavez, and K. Shields, "Antioxidants and antiinflammatory dietary supplements for osteoarthritis and rheumatoid arthritis," Alternative Therapies in Health and Medicine, vol. 16, pp. 32-40, 2010.

[18] T. H. Chou, H. Y. Ding, W. J. Hung, and C. H. Liang, "Antioxidative characteristics and inhibition of alpha-melanocyte-stimulating hormone-stimulated melanogenesis of vanillin and vanillic acid from Origanum vulgare," Experimental Dermatology, vol. 19, pp. 742-50, 2010.

[19] D. J. Charles, Antioxidant Properties of Spices, Herbs and Other Sources, Springer Science \& Business Media, Berlin, Germany, 2013.

[20] R. S. Verma, R. C. Padalia, A. Chauhan, R. K. Verma, A. K. Yadav, and H. P. Singh, "Chemical diversity in Indian oregano (Origanum vulgare L.)," Chemistry \& Biodiversity, vol. 7, no. 8, pp. 2054-2064, 2010.

[21] F. Adbellatif and A. Hassani, "Chemical composition of the essential oils from leaves of Melissa officinalis extracted by hydrodistillation, steam distillation, organic solvent and microwave hydrodistillation," Journal of Materials and Environmental Science, vol. 6, no. 1, pp. 207-213, 2015.

[22] R. P. Adams, Identification of Essential Oils Components by Gas Chromatography/Quadrupole Mass Spectroscopy, Allured Publishing Corporation, Illinois, IL USA, 2001.

[23] D. Punetha, G. Tewari, and C. Pande, "Compositional variability in inflorescence essential oil of Coriandrum sativum from North India," Journal of Essential Oil Research, vol. 30, no. 2, pp. 113-119, 2018.

[24] S. E. El-Bakkal, S. Zeroual, M. Elouazkiti et al., "Comparison of yield chemical composition and biological activities of essential oils obtained from Thymus pallidus and Thymus satureioides Coss. grown in wild and cultivated conditions in Morocco," Journal of Essential Oil Bearing Plants, vol. 23, no. 1, pp. 1-14, 2020.

[25] S. Jena, A. Ray, A. Banerjee et al., "Chemical composition and antioxidant activity of essential oil from leaves and rhizomes of Curcuma angustifolia Roxb," Natural Product Research, vol. 31, no. 18, pp. 2188-2191, 2017.

[26] W. Brand-Williams, M. E. Cuvelier, and C. Berset, "Use of a free radical method to evaluate antioxidant activity," LWT Food Science and Technology, vol. 28, no. 1, pp. 25-31, 1995.

[27] A. V. Leite, L. G. Malta, M. F. Riccio, M. N. Eberlin, G. M. Pastore, and M. R. Maróstica Júnior, “Antioxidant potential of rat plasma by administration of freeze-dried jaboticaba peel (Myrciaria jaboticaba Vell Berg)," Journal of Agricultural and Food Chemistry, vol. 59, no. 6, pp. 2277-2283, 2011.

[28] V. Maruthamuthu and R. Kandasamy, "Ferric reducing antioxidant power assay in plant extract," Bangladesh Journal of Pharmacology, vol. 11, pp. 570-572, 2016.

[29] E. A. Ainsworth and K. M. Gillespie, "Estimation of total phenolic content and other oxidation substrates in plant tissues using Folin-Ciocalteu reagent," Nature Protocols, vol. 2, no. 4, pp. 875-877, 2007.

[30] W. H. Lee and H. Safinar, "Antioxidant activity of total phenolics and total flavonoids of Syzygium polyanthum
(Wight) Walp leaves," International Journal of Medicinal and Aromatic Plants, vol. 2, pp. 219-228, 2012.

[31] S. Sadasivam and T. Balasubraminan, Practical Manual in Biochemistry, Tamil Nadu Agricultural University Coimbatore, Coimbatore, India, 1987.

[32] S. Goyal, R. Pathak, H. K. Pandey et al., "Comparative study of the volatile constituents of Thymus serpyllum L. grown at different altitudes of Western Himalayas," SN Applied Sciences, vol. 2, no. 7, p. 1208, 2020.

[33] M. Tajbakhsh, Ecology of Seeds, Jehad- Daneshgahi Publication, Urumia, Iran, 2008.

[34] M. Mahdavi, M. H. Jouri, J. Mahmoudi, F. Rezazadeh, and S. S. Mahzooni-Kachapi, "Investigating the altitude effect on the quantity and quality of the essential oil in Tanacetum polycephalum Sch.-Bip. polycephalum in the Baladeh region of Nour, Iran," Chinese Journal of Natural Medicines, vol. 11, no. 5, pp. 553-559, 2013.

[35] H. Habibi, D. Mazaheri, H. N. Majnoon, M. R. Chaeechi, M. Fakhr-Tabatabaee, and M. Bigdeli, "Effect of altitude on essential oil and components in wild thyme (Thymus kotschyanus Boiss.) Taleghan region," Pajouhesh \& Sazandegi (Agronomy and Horticulture), vol. 19, no. 4, pp. 2-10, 2006.

[36] A. M. Jamshidi, M. Aminzadeh, H. Azarnivand, and M. Abedi, "Effect of evaluation for quality and quantity of essential oil Thymus kotschyanus (Damavand-Tar)," Journal of Medicinal Plants, vol. 5, no. 18, pp. 17-22, 2006.

[37] M. S. Hajiabad, J. Novak, and B. Honermeier, "Content and composition of essential oil of four Origanum vulgare L. accessions under reduced and normal light intensity conditions," Journal of Applied Botany and Food Quality, vol. 89, pp. 126-134, 2016.

[38] D. Vokou, S. Kokkini, and J.-M. Bessiere, "Geographic variation of Greek oregano (Origanum vulgare ssp. hirtum) essential oils," Biochemical Systematics and Ecology, vol. 21, no. 2, pp. 287-295, 1993.

[39] L. F. D’Antuono, G. C. Galletti, and P. Bocchini, "Variability of essential oil content and composition of Origanum vulgare L. Populations from a North Mediterranean area (Liguria region, northern Italy)," Annals of Botany, vol. 86, pp. 471478, 2000.

[40] A. Sanli and T. Karadogan, "Geographical impact of essential oil composition of endemic Kundmannia Anatolic HubMOR. (Apiaceae)," African Journal of Traditional, Complementary and Alternative Medicines, vol. 14, no. 1, pp. 131-137, 2017.

[41] M. Milos, J. Mastelic, I. Jerkovic, and V. Katalinic, "Chemical composition and antioxidant activity of the essential oil of oregano (O. vulgare L.) grown wild in Croatia," Rivista Italiana Eppos, vol. 43, pp. 617-624, 2000.

[42] T. H. Chou, H. Y. Ding, W. H. Hung, and C. H. Liang, "Antioxidative characteristics and inhibition of $\alpha$-melanocyte-stimulating hormone-stimulated melanogenesis of vanillin and vanillic acid from Origanum vulgare," Experimental Dermatology, vol. 19, no. 8, pp. 742-750, 2010.

[43] L. Faleiro, G. Miguel, S. Gomes et al., "Antibacterial and antioxidant activities of essential oils isolated from Thymbra capitata L. (Cav.) and Origanum vulgare L.," Journal of Agricultural and Food Chemistry, vol. 53, no. 21, pp. 8162-8168, 2005.

[44] S. Koldaş, I. Demirtas, T. Ozen, M. A. Demirci, and L. Behçet, "Phytochemical screening, anticancer and antioxidant activities of Origanum vulgare L. ssp. viride (Boiss.) Hayek, a plant of traditional usage," Journal of the Science of Food and Agriculture, vol. 95, pp. 786-798, 2014. 
[45] S. R. C. Sena, T. R. F. Dantas, and C. G. Pereira, "Extracts from Thymus vulgaris and Origanum vulgare L. obtained by different separation processes: global yield and functional profile," Trends in Phytochemical Research, vol. 2, no. 1, pp. 13-20, 2018.

[46] N. K. Jain and N. Bhagia, "A comparative study of total phenolic, total flavonoid and antioxidant assays of aqueous and DMSO Extract from leaves of Origanum vulgare," World Journal of Pharmaceutical Sciences, vol. 5, no. 1, pp. 726-736, 2016.

[47] A. Govaris, N. Botsoglou, G. Papageorgiou, E. Botsoglou, and I. Ambrosiadis, "Dietary versus post-mortem use of oregano oil and/or $\alpha$-tocopherol in turkeys to inhibit development of lipid oxidation in meat during refrigerated storage," International Journal of Food Sciences and Nutrition, vol. 55, no. 2, pp. 115-123, 2004.

[48] A. Tomaino, F. Cimino, V. Zimbalatti et al., "Influence of heating on antioxidant activity and the chemical composition of some spice essential oils," Food Chemistry, vol. 89, no. 4, pp. 549-554, 2005.

[49] J. S. Raut and S. M. Karuppayil, "A status review on the medicinal properties of essential oils," Industrial Crops and Products, vol. 62, pp. 250-264, 2014.

[50] G. Ozkan, H. Baydar, and S. Erbas, "The influence of harvest time on essential oil composition, phenolic constituents and antioxidant properties of Turkish oregano (Origanum onites L.)," Journal of the Science of Food and Agriculture, vol. 90, no. 2, pp. 205-209, 2010.

[51] J. Coccimiglio, M. Alipour, Z. H. Jiang, C. Gottardo, and Z. Suntres, "Antioxidant, antibacterial, and cytotoxic activities of the ethanolic Origanum vulgare extract and its major constituents," Oxidative Medicine and Cellular Longevity, vol. 7, 2016.

[52] J. B. G. María, C. Espinosab, A. Francisco, M. Guardiolac, and E. Ángeles, "In vitro effects of Origanum vulgare leaf extracts on gilthead seabream (Sparus aurata L.) leucocytes, cytotoxic, bactericidal and antioxidant activities," Fish Shellfish Immunol, vol. 79, pp. 1-10, 2018.

[53] Origanum Vulgare L. Oregano. Plants Database, United States Department of Agriculture, http://plants.usda.gov/..

[54] R. Huang, E. Mendis, and S.-K. Kim, "Factors affecting the free radical scavenging behavior of chitosan sulfate," International Journal of Biological Macromolecules, vol. 36, no. 1-2, pp. 120-127, 2005.

[55] A. Ray, S. Jena, B. Dash et al., "Chemical diversity, antioxidant and antimicrobial activities of the essential oils from Indian populations of Hedychium coronarium Koen," Industrial Crops and Products, vol. 112, pp. 353-362, 2018. 